\title{
Another puzzle piece in the systematics of the chewing louse genus Myrsidea, with a description of a new genus Apomyrsidea
}

\author{
Stanislav KOLENCIK ${ }^{1, *}$, Oldřich SYCHRA ${ }^{2}$ \& Julie M. ALLEN ${ }^{3}$ \\ ${ }^{1,3}$ Department of Biology, University of Nevada, Reno, NV 89557, USA. \\ ${ }^{2}$ Department of Biology and Wildlife Diseases, Faculty of Veterinary Hygiene and Ecology, University \\ of Veterinary Sciences Brno, Palackeho tr. 1946/1, 61242 Brno, Czech Republic. \\ ${ }^{*}$ Corresponding author: skolencik@unr.edu \\ ${ }^{2}$ Email:sychrao@vfu.cz \\ ${ }^{3}$ Email: jallen23@unr.edu \\ ${ }^{1}$ urn:lsid:zoobank.org:author:AF343A9B-3D7D-45D7-9FC5-EEE51F990BA4 \\ ${ }^{2}$ urn:1sid:zoobank.org:author:D28CEAFB-0F34-4937-A66E-6AC8BA90E325 \\ ${ }^{3}$ urn:lsid:zoobank.org:author:2BB2810C-80D1-41C7-8DDF-1F8E0230E94E
}

\begin{abstract}
A new avian chewing louse genus Apomyrsidea gen. nov. is described based on species parasitizing birds in the family Formicariidae. Diagnostic characteristics and phylogenetic analyses were used to evaluate and confirm the generic status and merit its recognition as unique and different from Myrsidea Waterston, 1915. Three species previously belonging to the genus Myrsidea are placed in the new genus Apomyrsidea gen. nov. and are discussed: Apomyrsidea circumsternata (Valim \& Weckstein, 2013) gen. et comb. nov., Apomyrsidea isacantha (Valim \& Weckstein, 2013) gen. et comb. nov. and Apomyrsidea klimesi (Sychra in Sychra et al., 2006) gen. et comb. nov.
\end{abstract}

Keywords. Phthiraptera, Apomyrsidea, Myrsidea, morphology, phylogeny.

Kolencik S., Sychra O. \& Allen J.M. 2021. Another puzzle in the systematics of the chewing louse genus Myrsidea, with a description of a new genus Apomyrsidea. European Journal of Taxonomy 748: 36-50.

https://doi.org/10.5852/ejt.2021.748.1339

\section{Introduction}

Chewing lice (Psocodea Hennig, 1966: Phthiraptera Haeckel, 1896) are obligate permanent ectoparasites, meaning they live their entire life cycle on their hosts (Clayton et al. 2015). Many are microhabitat specialists, often occupying specific body parts on the host (Johnson et al. 2012). The species parasitizing birds feed on feathers, dead skin, skin secretions, and in some cases blood (Price et al. 2003). At high prevalence, they can cause significant harm to feathers, skin irritation and even possible secondary infections that decrease the fitness of the bird hosts (Møller et al. 1990; Mullen \& Durden 2002).

In the past, the taxonomy of chewing lice was based on morphology (Clay 1966; Price et al. 2003); however, in the last two decades, molecular and phylogenetic studies have helped to resolve the 
systematics of this diverse group (Johnson et al. 2004; Smith et al. 2011). The chewing lice genus Myrsidea Waterston, 1915 is among the most diverse and host specific genera within the parasitic lice (Phthiraptera), with more than 380 species described worldwide (Kolencik \& Sychra, unpublished data). While there are 49 species of Myrsidea described from Neotropical suboscine birds (Kolencik et al. 2018), only three have been described from birds of the family Formicariidae Gray, 1840 (Sychra et al. 2006; Valim \& Weckstein 2013). These three species show a set of characteristics that are unique among all species of Myrsidea to the extent that Sychra et al. (2006) and Valim \& Weckstein (2013) suggested that they may be placed outside of Myrsidea. Here, we evaluate both morphological and molecular data of these three species along with representatives of the major clades in Myrsidea. We find that the combination of differences found from both morphological and molecular data is strong enough to merit their recognition in a separate genus here named as Apomyrsidea gen. nov.

\section{Material and methods}

\section{Morphology}

All the morphological descriptions and characters as well as the terminology of chaetotaxy were taken from or follow those from Clay $(1961,1962,1966,1969)$, Sychra et al. (2006) and Valim \& Weckstein (2013). Taxonomy and nomenclature of the birds follows IOC Bird World List ver. 10.1 (Gill et al. 2020).

\section{Phylogenetic reconstruction}

For the phylogenetic reconstruction we used a fragment of the mitochondrial gene cytochrome oxidase I (COI, 379bp). We amplified and sequenced this fragment from Apomyrsidea klimesi (Sychra in Sychra et al., 2006) (3 nymphs ex Formicarius analis (d'Orbigny \& Lafresnaye, 1837) from Zona Protectora Las Tablas on the Pacific slope of the Cordillera de Talamanca, $8^{\circ} 54^{\prime} \mathrm{N}, 82^{\circ} 47^{\prime} \mathrm{W} ; 1300 \mathrm{~m}$ a.s.l.; identical sequences; GenBank accession number: MW381016) using the technique described by Martinu et al. (2015). All other sequences were downloaded from GenBank (Table 1) and aligned in SeaView ver. 4.7 (Gouy et al. 2010) using Clustal Omega (Sievers et al. 2011) and checked visually. In total, we aligned 50 sequences from seven chewing lice genera from the suborder Amblycera Kellogg, 1896 and two sequences from the suborder Ischnocera Kellogg, 1896 as the outgroups. To determine the best model fit to our data we used PartitionFinder ver. 2.1.1 (PF; Lanfear et al. 2016) and compared all models using the corrected Akaike Information Criterion (AICc). We selected two different approaches for a phylogenetic reconstruction to examine the similarity among the methods. First, the randomly accelerated maximum likelihood (RAxML ver. 8.2.12; Stamatakis 2014) method was used with three partitions and the model GTR $+\mathrm{I}+\mathrm{G}$ for each and estimated 1000 bootstrap trees. Second, MrBayes ver. 3.2 (Ronquist \& Huelsenbeck 2003) was used for Bayesian analysis with GTR + I + G model for two partitions and $\mathrm{HKY}+\mathrm{G}$ for the third. We conducted two parallel runs for 20000000 generations with four Markov chains (Huelsenbeck \& Bollback 2001), which were sampled every 1000 generations with a total of 20000 parameter points estimates. Markov chains were examined in Tracer ver. 1.7.1 (Rambaut et al. 2018) to determine that the chains had reached stationarity and $10 \%$ of trees were removed as burnin. A 50\% majority rule consensus tree with posterior probabilities was generated. The outgroup ischnoceran genus Philopterus Nitzsch, 1818 was used for rooting in both trees.

\section{Institutional abbreviations}

FMNH $=$ Field Museum of Natural History, Chicago, USA
INBio $=$ Instituto Nacional de Biodiversidad, Costa Rica
MMBC $=$ Moravian Museum, Brno, Czech Republic
MZUSP $=$ Museum of Zoology of the University of São Paulo, Brazil
NSF $=$ National Science Foundation, USA


Table 1 (continued on next page). List of the louse species included in our phylogenetic analyses, with their hosts and GenBank accession numbers. ${ }^{*}=$ in GenBank as species of Myrsidea $;{ }^{\dagger}=$ a new sequence.

\begin{tabular}{|c|c|c|}
\hline Lice species & Host species & GenBank number \\
\hline Actornithophilus ceruleus & Anous tenuirostris & AF545666 \\
\hline Actornithophilus erinaceus & Rostratula benghalensis & AF545667 \\
\hline Actornithophilus piceus & Larus sp. & AF545668 \\
\hline Apomyrsidea circumsternata* & Formicarius colma & KF048105 \\
\hline Apomyrsidea isacantha* & Chamaeza nobilis & KF048115 \\
\hline Apomyrsidea klimesi ${ }^{\dagger}$ & Formicarius analis & MW381016 \\
\hline Colpocephalum fregili & Corvus albus & MF443951 \\
\hline Colpocephalum indi & Ictinia mississippiensis & MF443945 \\
\hline Colpocephalum napiforme & Buteo lagopus & MF443947 \\
\hline Colpocephalum polybori & Caracara cheriway & MF443950 \\
\hline Colpocephalum subzerafae & Falco berigora & MF443946 \\
\hline Colpocephalum turbinatum & Circus approximans & MF443944 \\
\hline Dennyus bartoni & Aerodramus mearnsi & DQ139300 \\
\hline Dennyus carljonesi carljonesi & Aerodramus v. vestitus & DQ139294 \\
\hline Dennyus carljonesi forresteri & Aerodramus elaphrus & DQ139297 \\
\hline Dennyus carljonesi forresteri & Aerodramus francicus & DQ139296 \\
\hline Dennyus kristinae & Aerodramus s. spodiopygius & DQ139305 \\
\hline Dennyus mimirogerorum & Aerodramus papuensis & DQ139301 \\
\hline Dennyus singhi & Aerodramus assimilis & DQ139307 \\
\hline Menacanthus alaudae & Calamonastes fasciolatus & MG682392 \\
\hline Menacanthus alaudae & Plocepasser mahali & MG682398 \\
\hline Menacanthus camelinus & Lanius collaris & MG682399 \\
\hline Menacanthus eurysternus & Curruca subcoerulea & MG682400 \\
\hline Menacanthus eurysternus & Prinia flavicans & MG682401 \\
\hline Menacanthus eurysternus & Turdus libonyana & MG682393 \\
\hline Menacanthus eurysternus & Melaenornis silens & MG682384 \\
\hline Menacanthus eurysternus & Turdus merula & KJ730692 \\
\hline Menacanthus sp. & Lagonosticta rara & DQ887248 \\
\hline Menacanthus sp. & Pogoniulus chrysoconus & MG682396 \\
\hline Menacanthus takayamai & Locustella luscinioides & KJ730535 \\
\hline Myrsidea alexanderi & Pheugopedius maculipectus & MF563536 \\
\hline Myrsidea argentina & Spinus magellanicus & KY113129 \\
\hline Myrsidea cecilae & Ramphastos culminatus $\times$ ariel & KF048126 \\
\hline Myrsidea cf. bubalornithis & Bubalornis niger & MG682394 \\
\hline Myrsidea cf. textoris & Ploceus ocularis & MG682397 \\
\hline Myrsidea cinnamomei & Attila citriniventris & KF048110 \\
\hline Myrsidea contopi & Leptopogon amaurocephalus & MF563537 \\
\hline Myrsidea cruickshanki & Chlorothraupis carmioli & GQ454449 \\
\hline Myrsidea icterocephalae & Tangara icterocephala & KF048103 \\
\hline Myrsidea incerta & Catharus ustulatus & FJ171268 \\
\hline Myrsidea seminuda & Thraupis palmarum & KF048116 \\
\hline Myrsidea valimi & Euphonia anneae & GQ454450 \\
\hline
\end{tabular}


KOLENCIK S. et al., A new louse genus Apomyrsidea gen. nov. (Phthiraptera)

Table 1 (continued). List of the louse species included in our phylogenetic analyses, with their hosts and GenBank accession numbers. ${ }^{*}=$ in GenBank as species of Myrsidea ${ }^{\dagger}{ }^{\dagger}=$ a new sequence.

\begin{tabular}{lll}
\hline Lice species & Host species & GenBank number \\
\hline Myrsidea violaceae & Euphonia hirundinacea & KY113137 \\
Ricinus mugimaki & Cossypha dichroa & KF768816 \\
Ricinus sp. & Atila spadiceus & AF545762 \\
Ricinus sp. & Cyanocompsa parellina & AF545763 \\
Ricinus sp. & Ficedula hyperythra & AF545764 \\
Ricinus sp. & Fringillaria tahapisi & MG682387 \\
Ricinus sp. & Platysteira laticincta & MK032013 \\
Ricinus sp. & Terpsiphone batesi & KU187311 \\
Ricinus sp. & Terpsiphone viridis & KY359404 \\
\hline Outgroups & & \\
\hline Philopterus solus & Rhinopomastus cyanomelas & MG682416 \\
Traihoriella laticeps & Andigena nigrirostris & AY149398 \\
\hline
\end{tabular}

\section{Results}

Here, we find that species of Apomyrsidea gen. nov. are unique and morphologically distinct from all species of Myrsidea. Specifically, the simple combination of the presence of the posterior dorsal head seta (dhs) 23 and the dorso-central pronotal setae (dps) 2 (Fig. 3), sternite I lying inside the wide notch of sternite II (Fig. 5) and different type of fusion in the terminal sternites - male abdominal sternite VIII and female sternite VII both at least partially but conspicuously separated from the subgenital plate, which is formed by a single sternite IX (in the male; Fig. 2) or fusion of sternites VIII and IX (in the female; Fig. 1), make these species distinct. These characters were further defined in Clay (1966), Sychra et al. (2006) and Valim \& Weckstein (2013).

This separation is also supported with the present phylogenetic analyses of $379 \mathrm{bp}$ fragment of COI from 50 amblyceran species across 6 genera: Actornithophilus Ferris, 1916, Colpocephalum Nitzsch, 1818, Dennyus Neumann, 1906, Myrsidea (including all three species of Myrsidea occurring on formicariid hosts that are here placed in Apomyrsidea gen. nov.), Menacanthus Neumann, 1912 and Ricinus De Geer, 1778, and with two ischnoceran lice, Traihoriella laticeps (Piaget, 1888) and Philopterus solus (Tendeiro, 1962), as outgroups (Fig. 10). Both Bayesian analysis and Maximum Likelihood analysis (Appendix) resulted in trees with a similar topology, differing in some intra-generic relationships. However, both trees coincide in topology of our main focus, 'Myrsidea from Formicariidae' - Apomyrsidea gen. nov., and place it sister to all other species of Myrsidea.

Class Insecta Linnaeus, 1758

Superorder Psocodea Hennig, 1966

Order Phthiraptera Haeckel, 1896

Suborder Amblycera Kellogg, 1896

Family Menoponidae Mjöberg, 1910

Genus Apomyrsidea gen. nov. urn:1sid:zoobank.org:act:5A86DF15-251D-4262-9BDF-92A3E1BE9C6C

Myrsidea Waterston, 1915: 12 (in partim). 


\section{Type species}

Apomyrsidea klimesi (Sychra in Sychra et al., 2006: 55) gen. et comb. nov.

\section{Diagnosis}

Apomyrsidea can be characterized and distinguished from all other menoponid chewing lice genera with the combination of following characteristics:

\section{Head}

- rounded anteriorly, lacking lateral slit or notch, without sclerotized processes (oral spines) arising near the base of maxillary palpi (Figs $1-3$ );
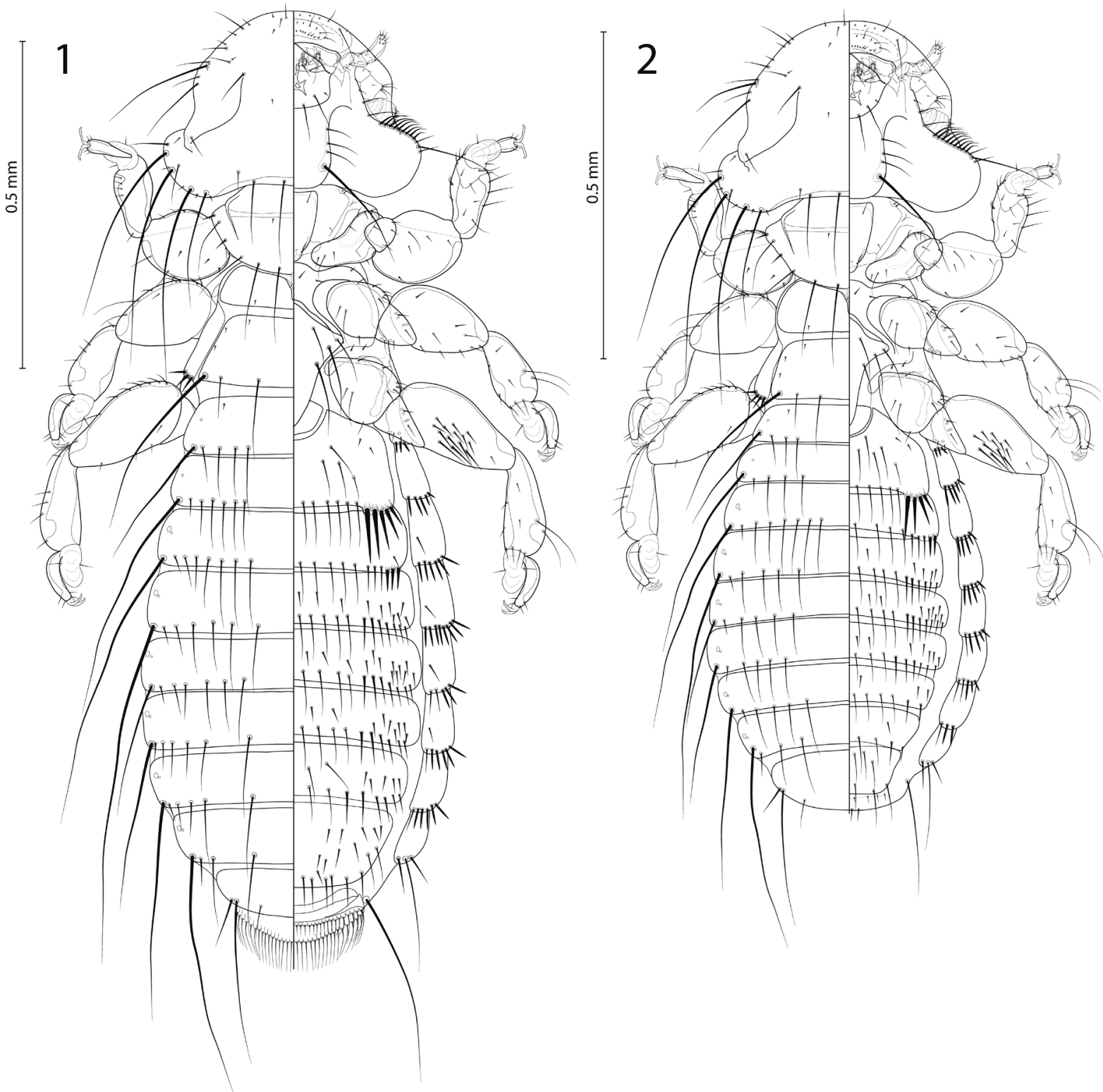

Figs 1-2. Dorso-ventral view of Apomyrsidea klimesi (Sychra in Sychra et al., 2006) gen. et comb. nov. (CR15). 1. ‥ 2. $\jmath^{\text {. }}$. 
- alveoli of dorsal head setae (dhs; marginal temporal setae by Clay 1969) 26 and 27 not closely associated (Fig. 3);

- dhs 18 (outer mid-dorsal head seta by Clay (1966) or dorsal head seta „d“ by Clay (1962) is missing;

- dhs 22 (outer occipital seta by Valim \& Weckstein 2013 or posterior dorsal head seta „f“ by Clay 1962) approximately as long as dhs 21 (inner occipital seta by Valim \& Weckstein 2013), both surpassing pronotal carina;

- dhs 23 (posterior dorsal head seta "e" in Clay 1962) present and anteriorly to line of bases of $d h s 21$ and 22 (Fig. 3);

- head sensilla 3-5 sensu Clay (1961) or c-e sensu Clay (1969) absent;

- characteristic gular plate with the greater length and thickness of the posterior pair of setae compared to the rest ones (Figs 1-2).

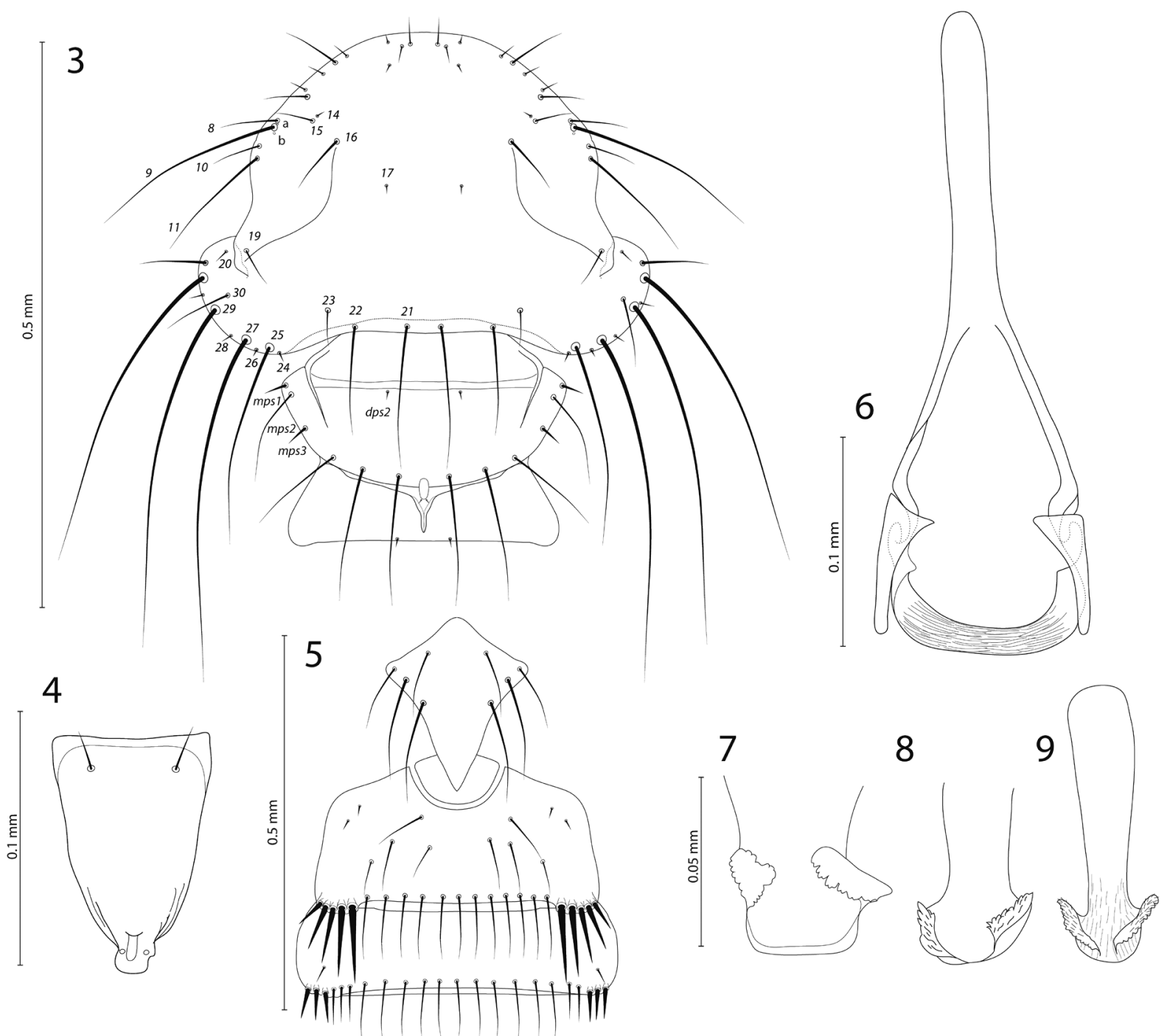

Figs 3-9. 3-6. Apomyrsidea klimesi (Sychra in Sychra et al., 2006) gen. et comb. nov. (CR15). 3. Dorsal view of head, prothorax and mesothorax of female. 4. Prosternal plate of female. 5. Metasternal plate and sternites I-III of female. 6. Male genitalia. - 7-9. Male genital sac sclerites. 7. A. klimesi gen. et comb. nov. 8. A. circumsternata (Valim \& Weckstein, 2013) gen. et comb. nov. 9. A. isacantha (Valim \& Weckstein, 2013) gen. et comb. nov. Abbreviations: $\mathrm{a}-\mathrm{b}=$ head sensilla; $d p s=$ dorso-central pronotal setae; $m p s=$ marginal prothoracic setae; $8-30=$ dorsal head setae. Figs $7-9$ are drawn to the same scale. 


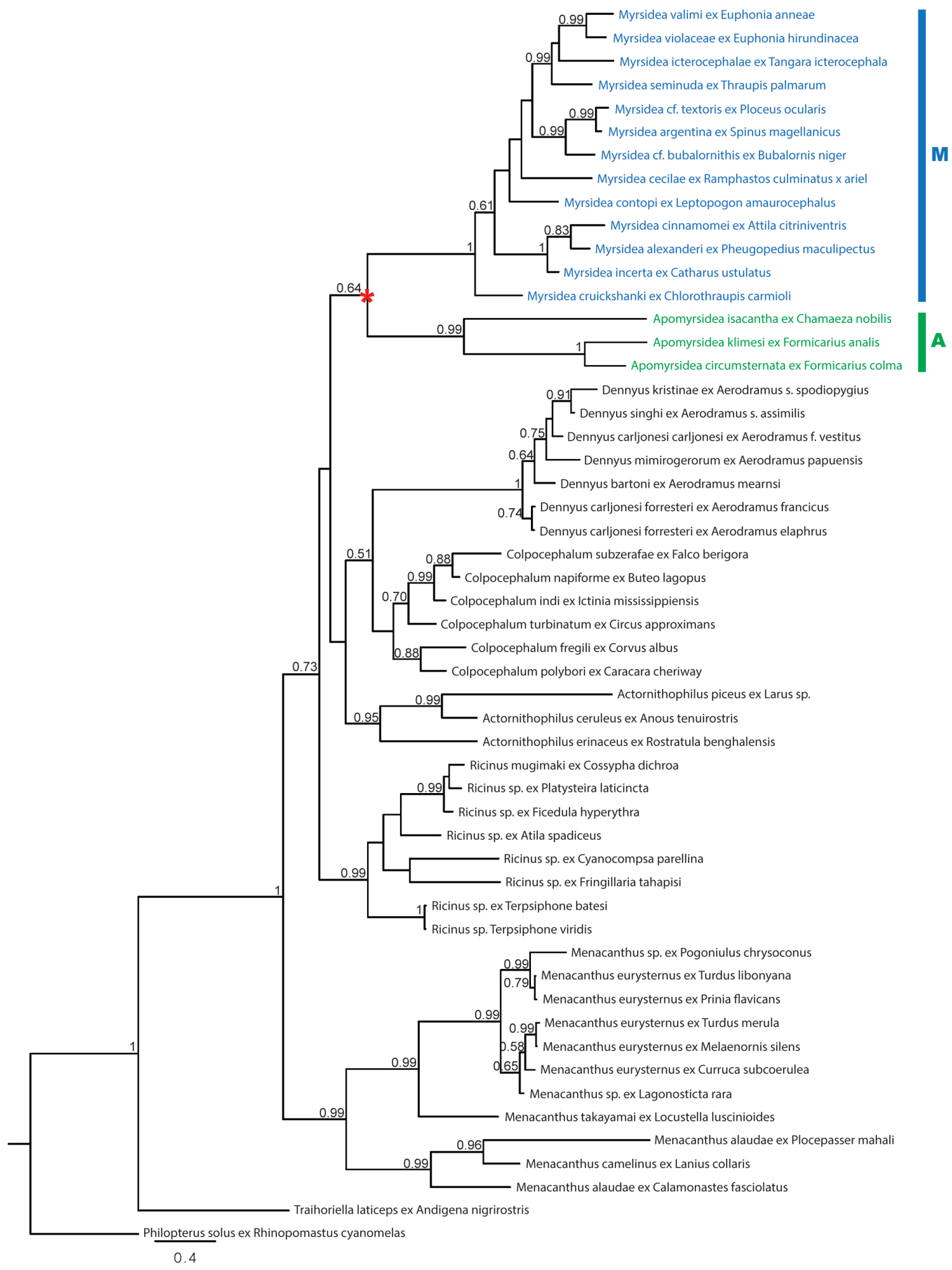

Fig. 10. Bayesian phylogenetic tree of selected amblyceran genera and species based on partial mitochondrial gene COI. Tree is rooted with outgroup species Philopterus solus (Tendeiro, 1962). Posterior probability values are shown above the nodes (values $<50 \%$ are not shown). Blue colour indicates species of Myrsidea Waterston, 1915 (M); green colour indicates species of Apomyrsidea gen. nov. (A); * symbol indicates a node between Myrsidea and Apomyrsidea. 


\section{Thorax}

- prosternal plate well developed with straight anterior margin and two anterior setae (Fig. 4);

- pronotum with one pair of minute dorso-central pronotal setae lying near the transverse carina ( $d p s 2$ by Clay 1962) (Fig. 3);

- pronotum with anterolateral pronotal setae (marginal prothoracic setae 1-3, mps 1-3 in Clay 1962) in following arrangement: mps 1 and mps 3 spine-like, mps 2 fine and long; mps 1 and mps 2 located on each lateral corner of pronotum, with mps 3 posteriorly to mps 2 on pronotal margin (Fig. 3);

- mesonotum well defined with only two anterior setae;

- mesonotum without median division, but with a Y-shaped line just below postnotum, not forming a suture or even splitting mesonotum (Fig. 3). This Y-shaped line slightly less evident, but also discernible in good specimens from other host families;

- strongly sclerotized ring-like mesothorax - mesothorax with sternum, pleura and tergum fused to form strongly sclerotized ring round the body;

- femur III without combs of spine-like setae but with thick or sparse brushes of setae.

\footnotetext{
Abdomen

- sternite I mostly surrounded by sternite II (it lies inside the wide notch of sternite II) (Fig. 5);

- sternite II enlarged with a clutch of heavy spine-like setae at each posterior-lateral margin called aster;

- male genitalia as in Fig. 6.

- male genital sac sclerite with two roughly serrated spiculated lateral arms (Figs 7-9);

- female vulva with smooth posterior margin (Fig. 1);

- female ventral anal margin without lateral seta-bearing processes (see Clay 1969);

- sternite VII fused with VIII + IX + X, forming female subgenital plate, although with a distinct transverse fenestra distinctly enclosed at lateral sides of subgenital plate where seventh and eighth segments fused (in A. circumsternata and A. isacantha; see Valim \& Weckstein 2013: fig. 11); in the case of $A$. klimesi - male abdominal sternite VIII and female sternite VII both separated from the subgenital plate, which is formed by a single sternite IX (in the male) or fusion of sternites VIII and IX (in the female) (Figs 1-2).
}

\section{Etymology}

The generic name Apomyrsidea is formed by a combination of Greek word 'Apo' = 'from' and Myrsidea, referring that it is separated from the genus Myrsidea, where it was originally placed. The gender is feminine.

\section{Included species}

Three species are included in the Apomyrsidea gen. nov., all are restricted to formicariid hosts:

Apomyrsidea circumsternata (Valim \& Weckstein, 2013) gen. et comb. nov.

Apomyrsidea isacantha (Valim \& Weckstein, 2013) gen. et comb. nov.

Apomyrsidea klimesi (Sychra in Sychra et al., 2006) gen. et comb. nov.

Descriptions of all three species are well presented in the original papers (Sychra et al. 2006; Valim \& Weckstein 2013). Valim \& Weckstein (2013) also presented a key to their identification.

Apomyrsidea circumsternata (Valim \& Weckstein, 2013) gen. et comb. nov. Figs 8, 10

Myrsidea circumsternata Valim \& Weckstein, 2013: 383, figs 3-4, 13-15, 17, 19, 22 (type host: Formicarius colma Boddaert, 1783). 


\section{Material examined}

\section{Holotype}

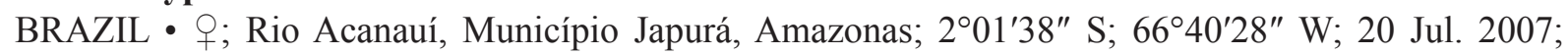
Weckstein leg.; ex Formicarius colma Boddaert, 1783; MZUSP 2314.

\section{Paratypes $(2$ 우, $3 \hat{\jmath} \hat{)})$}

BRAZIL • $1 \partial^{\lambda}$; same collection data as for holotype; FMNH-INS $94002 \cdot 1$ q ; same collection data as for holotype; DNA voucher Mysp.Foco.1.4.2011.3; FMNH-INS 94003 • 2 ôे; same collection data as for holotype; MZUSP 2316, MZUSP $2317 \bullet 1$ क ; same collection data as for holotype; MZUSP 2315.

Apomyrsidea isacantha (Valim \& Weckstein, 2013) gen. et comb. nov.

Figs 9-10

Myrsidea isacantha Valim \& Weckstein, 2013: 381, figs 1-2, 11-12, 16, 18, 20-21 (type host: Chamaeza nobilis Gould, 1855).

\section{Material examined}

\section{Holotype}

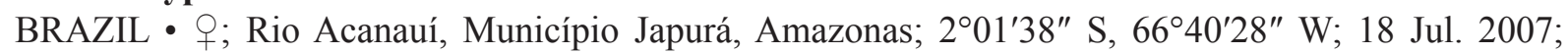
Weckstein leg.; ex Chamaeza nobilis Gould, 1855; MZUSP 2310.

\section{Paratypes $(2+q, 3$ $ぇ)$}

BRAZIL • 1 ; ; same collection data as for holotype; FMNH-INS $94000 \bullet 1+$; same collection data as

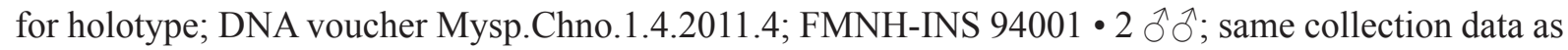
for holotype; MZUSP 2312, MZUSP 2313•1 9 ; same collection data as for holotype; MZUSP 2311.

Apomyrsidea klimesi (Sychra in Sychra et al., 2006) gen. et comb. nov.

Figs $1-7,10$

Myrsidea klimesi Sychra in Sychra et al., 2006: 55, figs 10-11, 14-15 (type host: Formicarius analis

(d'Orbigny \& Lafresnaye, 1837)).

\section{Material examined}

\section{Holotype}

COSTA RICA - ; ; Hitoy Cerere BR, Provincia Limón; 940’ N, 85²7' W; 100 m a.s.1.; 27 Aug. 2004; Literak, Capek and Havlicek leg.; ex Formicarius analis (d'Orbigny \& Lafresnaye, 1837); INBio O.Sychra CR15.

\section{Allotype}

COSTA RICA • ${ }^{\lambda}$; same collection data as for holotype; INBio O.Sychra CR15.

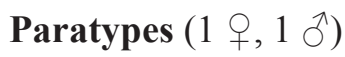

COSTA RICA • 1 +, 1 \% ; same collection data as for holotype; 27 and 31 Aug. 2004; INBio O.Sychra CR14, CR16.

\section{Other material}

COSTA RICA -1 ; Zona Protectora Las Tablas on the Pacific slope of the Cordillera de Talamanca; $8^{\circ} 54^{\prime} \mathrm{N}, 82^{\circ} 47^{\prime} \mathrm{W} ; 1300 \mathrm{~m}$ a.s.1.; 21. Aug. 2010; Sychra and Literak leg.; ex Formicarius analis; MMBC O.Sychra CR226. 


\section{Discussion}

In the key to the genera of the Menoponidae Mjöberg, 1910 of Clay (1969), Apomyrsidea gen. nov. would key to couplet 33 being closest to Myrsidea and Oculomenopon Price \& Hellenthal, 2005. All three genera share unique diagnostic characters including: characteristic gular plate with the greater length and thickness of the posterior pair of setae compared to the other ones; missing $d h s$ 18; well-developed prosternal plate with two anterior setae; strongly sclerotized ring-like mesothorax - mesothorax with sternum, pleura and tergum fused to form strongly sclerotized ring round the body; and general shape of male genitalia. Moreover, enlarged sternite II with aster of heavy setae at each posterior corner is a common feature of Apomyrsidea gen. nov. and Myrsidea, while presence of $d h s 23$ and the similar size of dhs 21 and dhs 22 is shared between Apomyrsidea gen. nov. and Oculomenopon (Price \& Hellenthal 2005).

The most important key characters useful for separating Apomyrsidea gen. nov. from all species of Myrsidea and Oculomenopon are: the presence of $d p s$ 2, sternite I lying inside the wide notch of sternite II and different type of fusion in the terminal sternites - male abdominal sternite VIII and female sternite VII both at least partially but conspicuously separated from the subgenital plate, which is formed by a single sternite IX (in the male) or fusion of sternites VIII and IX (in the female).

Here, we provide a key for these three genera that modifies and extends the first part of couplet 33 of the Clay's (1969) key as follows:

33. Prosternum with 2 central setae.

33a. Dps 2 present; sternite I mostly surrounded by sternite II (it lies inside the wide notch on anterior margin of sternite II)...... Apomyrsidea gen. nov.

- Both $d p s$ absent; sternite I lies above the sternite II that has straight anterior margin without notch $33 b$

33b. Dhs 23 absent Myrsidea Waterston, 1915

- Dhs 23 present Oculomenopon Price \& Hellenthal, 2005

Valim \& Weckstein (2013) also discussed the presence of $d p s 2$ and stated that, according to Clay (1966), the absence of dorso-central pronotal setae ( $d p s 1$ and $d p s$ 2) is one of defining characteristics of the genus Myrsidea. They wrongly interpreted Clay (1969), when writing: "Clay (1969) presented data showing that some species of Myrsidea could have at least one pair of dorso-central pronotal setae (see couplet 32)". When we checked couplet 32 in the key by Clay (1969), there is a note "not more than one pair of dorso-central pronotal setae". Moreover, Clay (1969: 11) wrote: "There are usually two pairs of dorso-central pronotal setae ( $d p s)$ lying on or near the transverse carina, but in some species-groups (Clay 1962: 237) or genera (Myrsidea) they are reduced to one pair or absent." We have examined many slides across groups and species of Myrsidea and can confirm that $d p s$ are absent apart from the newly erected Apomyrsidea.

Another interesting character is the presence of a cluster of heavy setae on each side of sternite III (Fig. 5). These setae are not as long as the aster, but they are heavier than spine-like setae on the lateral sides of other sternites and they are more conspicuous on females than on males. Despite this, it cannot be used as a basic character of the genus, because it is present only in two species - A. circumsternata gen. et comb. nov. and A. klimesi gen. et comb. nov. An unusual cluster of three spine-like setae situated on one side of sternite III was described by Klockenhoff (1984) from only one female of M. serini (Séguy, 1944). To our knowledge, no other author referred to such a structure on sternite III and we have not found it in any other examined Myrsidea. 
A partial division of terminal sternites in females is known for example in some Myrsidea from bulbuls (Pycnonotidae G.R. Gray, 1840; Hellenthal \& Price 2003), or Myrsidea abbreviata Eichler, 1951 from Ramphastos dicolorus Linnaeus, 1766 (Piciformes Meyer \& Wolf, 1810: Ramphastidae Vigors, 1825; Price et al. 2004). However, this partial division is noticeable only at the lateral margins of the sternites of these species. A medial division or totally divided terminal sternites are only found in species of Apomyrsidea. According to Clay (1969), this is not necessarily a generic character, but in our opinion, it can be useful for separating Apomyrsidea gen. nov. from Myrsidea.

Another interesting character is the length of $d h s 21$ and $d h s$ 22. While Clay (1966) considered the short length of $d h s 22$ compared with the long $d h s 21$ as one of the determining characteristics for the genus Myrsidea, Apomyrsidea gen. nov. shows $d h s 22$ as long as $d h s 21$ and both exceed the pronotal carina. Interestingly, the enigmatic genus Ramphasticola Carriker, 1949, which has been difficult to place, with different authors suggesting it should be nested within Myrsidea (Hopkins \& Clay 1952; Price et al. 2003), has both species with long and short $d h s 22$, further suggesting a molecular phylogenetic analysis is needed to validate the placement of this genus.

The presence of an aster of heavy setae at each posterior corner of sternite II in Apomyrsidea gen. nov. and Myrsidea may bring some new challenges to determinations. The aster is one of the most visible features of many species of Myrsidea, and easily seen even under a stereoscope. However, in some species of Myrsidea it can be reduced (e.g., some species of Ramphastidae), while in species of Apomyrsidea gen. nov. it is always present. This changes the defining characteristic of the aster as the determining morphological feature for Myrsidea and broadens the use of this characteristic to a second genus. Henceforth, if no aster is present in a louse, this does not necessarily mean that it is not a Myrsidea, but the presence of asters will narrow the selection to two genera: Myrsidea and Apomyrsidea gen. nov. This further supports this character as an important one for morphological identifications.

Beside unique morphological characteristics, Valim \& Weckstein (2013) referred to these species as "Myrsidea from Formicariidae" and suggested they would be phylogenetically distinct from nearly all other species of Myrsidea. Therein, instead of describing the new genus, the authors decided to broaden the set of diagnostic characters used to define the genus Myrsidea. However, in their phylogenetic tree Myrsidea sp. (GenBank KF048123) from Myiarchus panamensis Lawrence, 1861 (the avian family Tyrannidae Vigors, 1825), appears to be in the same clade with both species of Apomyrsidea gen. nov. used in the analysis (Valim \& Weckstein 2013). This may be a misidentification of the sample and needs validation. Further, when this sequence was compared to all other COI sequences (a $379 \mathrm{bp}$ fragment of mitochondrial gene cytochrome oxidase subunit I) in GenBank, the highest match was Menacanthus sp. (GenBank AF545726) from the tyrannid Attila spadiceus (Gmelin J.F., 1789), with a p-distance of only $0.79 \%$, and Menacanthus sp. (GenBank KJ730539) from the parid Poecile sp. with a p-distance of $1.31 \%$. A comparison between these two species of Menacanthus showed the p-distance to be $1.05 \%$, which is likely low enough to confirm it as the same species. On the basis of these facts, we believe that sequence KF048123 is potentially an untrustful sequence and we excluded it from our analysis.

When we used a broader range of genera in our study, Apomyrsidea gen. nov. shows a similar pattern creating a well separated clade from all other species of Myrsidea (Fig. 10). The familiar issue with lower support values (mostly in basal nodes) is often present when using only a single gene fragment (e.g., Kolencik et al. 2017). Unfortunately, the sequences, and their quality, for amblyceran species submitted to the GenBank database are limited and mostly only for a 379bp fragment of COI and/ or a $347 \mathrm{bp}$ fragment of nuclear EF-1a (elongation factor 1 alpha) gene. Besides that, in many cases both sequences for the same specimen did not overlap; moreover, all three species of Apomyrsidea gen. nov. have only data for COI. Thus, it leaves a 379bp COI's fragment as the only one eligible for this study. The COI topology shows that A. klimesi gen. et comb. nov. is sister to A. circumsternata gen. et 
comb. nov., in accordance with their morphology, which was also used in the key for their identification by Valim \& Weckstein (2013).

In conclusion, the combination of unique morphological characteristics and the well-separated clade in the phylogenetic tree are strong enough to confirm Apomyrsidea gen. nov. as a new genus, and a sister taxon to Myrsidea.

\section{Acknowledgements}

This study was supported by NSF grant DEB-1925312. We are indebted to Michel Valim (Biotério da Universidade Iguaçu, Nova Iguaçu, Rio de Janeiro, Brazil), for his long-term cooperation and years of discussion about the taxonomy of Myrsidea and chewing lice in general. We are also very indebted to our colleagues Jana Martinu and Ivo Papousek for their help in amplifying and processing the sequences from Apomyrsidea klimesi gen. et comb. nov.

\section{References}

Clay T. 1961. A new genus and species of the Menoponidae (Mallophaga, Insecta) from Apteryx. Annals and Magazine of Natural History (Series 13) 3: 571-576. https://doi.org/10.1080/00222936008651059

Clay T. 1962. A key to the species of Actornithophilus Ferris with notes and descriptions of new species. Bulletin of the British Museum (Natural History) Entomology 11: 189-244.

Clay T. 1966. Contributions towards a revision of Myrsidea Waterston. I. (Menoponidae: Mallophaga). Bulletin of the British Museum (Natural History) Entomology 17: 327-395.

https://doi.org/10.5962/bhl.part.14816

Clay T. 1969. A key to the genera of the Menoponidae (Amblycera: Mallophaga: Insecta). Bulletin of the British Museum (Natural History) Entomology 24: 3-26. https://doi.org/10.5962/bhl.part.1517

Clayton D.H., Bush S.E. \& Johnson K.P. 2015. Coevolution of Life on Hosts: Integrating Ecology and History. University of Chicago Press. https://doi.org/10.7208/chicago/9780226302300.001.0001

Gill F., Donsker D. \& Rasmussen P. (eds). 2020. IOC World Bird List (ver. 10.1). https://doi.org/10.14344/IOC.ML.10.0

Gouy M., Guindon S. \& Gascuel O. 2010. SeaView version 4: a multiplatform graphical user interface for sequence alignment and phylogenetic tree building. Molecular Biology and Evolution 27: 221-224. https://doi.org/10.1093/molbev/msp259

Hellenthal R.A. \& Price R.D. 2003. The genus Myrsidea Waterston (Phthiraptera: Menoponidae) from bulbuls (Passeriformes: Pycnonotidae), with descriptions of 16 new species. Zootaxa 354: 1-20. https://doi.org/10.11646/zootaxa.354.1.1

Hopkins G.H.E. \& Clay T. 1952. A Check List of the Genera and Species of Mallophaga. Trustees of the British Museum (Natural History), London. https://doi.org/10.5962/bhl.title.118844

Huelsenbeck J.P. \& Bollback J.P. 2001. Empirical and hierarchical Bayesian estimation of ancestral states. Systematic Biology 50: 351-366. https://doi.org/10.1080/10635150119871

Johnson K.P., Yoshizawa K. \& Smith V.S. 2004. Multiple origins of parasitism in lice. Proceedings of the Royal Society of London B 271: 1771-1776. https://doi.org/10.1098/rspb.2004.2798

Johnson K.P., Shreve S.M. \& Smith V.S. 2012. Repeated adaptive divergence of microhabitat specialization in avian feather lice. BMC biology 10: 52. https://doi.org/10.1186/1741-7007-10-52 
Klockenhoff H.F. 1984. A redescription of Myrsidea serini (Mallophaga: Menoponidae), a parasite from passerine birds. New Zealand Journal of Zoology 11: 17-22.

https://doi.org/10.1080/03014223.1984.10428223

Kolencik S., Sychra O., Papousek I. \& Literak I. 2017. Where are the species limits? Morphology versus genetics in Neotropical chewing lice of the genus Myrsidea (Phthiraptera: Menoponidae), with description of three new species. Zootaxa 4324: 161-179.

https://doi.org/10.11646/zootaxa.4324.1.9

Kolencik S., Sychra O., Papousek I., Kuabara K.M.D., Valim M.P. \& Literak I. 2018. New species and additional data on the chewing louse genus Myrsidea (Phthiraptera: Menoponidae) from wild Neotropical Passeriformes (Aves). Zootaxa 4418: 401-431. https://doi.org/10.11646/zootaxa.4418.5.1

Lanfear R., Frandsen P.B., Wright A.M., Senfeld T. \& Calcott B. 2016. PartitionFinder 2: new methods for selecting partitioned models of evolution for molecular and morphological phylogenetic analyses. Molecular Biology and Evolution 34: 772-773. https://doi.org/10.1093/molbev/msw260

Martinu J., Sychra O., Literak I., Capek M., Gustafsson D.L. \& Stefka J. 2015. Host generalists and specialists emerging side by side: an analysis of evolutionary patterns in the cosmopolitan chewing louse genus Menacanthus. International Journal of Parasitology 45: 63-73.

https://doi.org/10.1016/j.ijpara.2014.09.001

Møller A.P., Allander K. \& Dufva R. 1990. Fitness effects of parasites on passerine birds: A review. In: Blondel J., Gosler A., Lebreton J. \& McCleery R.H. (eds) Population Biology of Passerine Birds: 269-280. Springer-Verlag, Berlin. https://doi.org/10.1007/978-3-642-75110-3_23

Mullen G. \& Durden L. (eds). 2002. Medical and Veterinary Entomology. Academic Press, London.

Price R.D. \& Hellenthal R.A. 2005. A new genus and new species of chewing louse (Phthiraptera: Menoponidae) from the lesser Melampitta (Aves: Passeriformes). Journal of the Kansas Entomological Society 78: 167-171. https://doi.org/10.2317/0406.01.1

Price R.D., Hellenthal R.A., Palma R.L., Johnson K.P. \& Clayton D.H. 2003. The Chewing Lice: World Checklist and Biological Overview. Illinois Natural History Survey Special Publication 24. Illinois Department of Natural Resources, Springfield, IL. https://doi.org/10.5962/bhl.title.154191

Price R.D., Hellenthal R.A. \& Weckstein J.D. 2004. The genus Myrsidea Waterston (Phthiraptera: Menoponidae) from the toucans (Piciformes: Ramphastidae), with descriptions of three new species. Zootaxa 613: 1-18. https://doi.org/10.11646/zootaxa.613.1.1

Rambaut A., Drummond A.J., Xie D., Baele G. \& Suchard M.A. 2018. Posterior summarization in Bayesian phylogenetics using Tracer 1.7. Systematic Biology 67: 901-904.

https://doi.org/10.1093/sysbio/syy032

Ronquist F. \& Huelsenbeck J.P. 2003. MrBayes 3: Bayesian phylogenetic inference under mixed models. Bioinformatics 19: 1572-1574. https://doi.org/10.1093/bioinformatics/btg180

Sievers F., Wilm A., Dineen D.G., Gibson T.J., Karplus K., Li W., Lopez R., McWilliam H., Remmert M., Söding J., Thompson J.D. \& Higgins D.G. 2011. Fast, scalable generation of high-quality protein multiple sequence alignments using Clustal Omega. Molecular Systems Biology 7: 539.

https://doi.org/10.1038/msb.2011.75

Smith V.S., Ford T., Johnson K.P., Johnson P.C.D., Yoshizawa K. \& Light J.E. 2011. Multiple lineages of lice pass through the K-Pg boundary. Biology Letters 7: 782-785. https://doi.org/10.1098/rsbl.2011.0105

Stamatakis A. 2014. RAxML version 8: a tool for phylogenetic analysis and post-analysis of large phylogenies. Bioinformatics 30: 1312-1313. https://doi.org/10.1093/bioinformatics/btu033 
Sychra O., Literak I., Čapek M. \& Havlíček M. 2006. Chewing lice (Phthiraptera) from typical antbirds and ground antbirds (Passeriformes: Thamnophilidae, Formicariidae) from Costa Rica, with descriptions of three new species of the genera Formicaphagus and Myrsidea. Zootaxa 1206: 47-61. https://doi.org/10.11646/zootaxa.1206.1.3

Valim M.P. \& Weckstein J.D. 2013. A drop in the bucket of the megadiverse chewing louse genus Myrsidea (Phthiraptera, Amblyclera, Menoponidae): ten new species from Amazonian Brazil. Folia Parasitologica 60: 377-400. https://doi.org/10.14411/fp.2013.040

Waterston J. 1915. On two new species of Mallophaga (Menoponidae): Menacanthus balfouri n. sp. and Myrsidea victrix n. sp. from Colombia. Entomologist's Monthly Magazine 51: 12-16.

https://doi.org/10.5962/bhl.part.7786

Manuscript received: 7 July 2020

Manuscript accepted: 3 March 2021

Published on: 3 May 2021

Topic editor: Nesrine Akkari

Desk editor: Kristiaan Hoedemakers

Printed versions of all papers are also deposited in the libraries of the institutes that are members of the EJT consortium: Muséum national d'histoire naturelle, Paris, France; Meise Botanic Garden, Belgium; Royal Museum for Central Africa, Tervuren, Belgium; Royal Belgian Institute of Natural Sciences, Brussels, Belgium; Natural History Museum of Denmark, Copenhagen, Denmark; Naturalis Biodiversity Center, Leiden, the Netherlands; Museo Nacional de Ciencias Naturales-CSIC, Madrid, Spain; Real Jardín Botánico de Madrid CSIC, Spain; Zoological Research Museum Alexander Koenig, Bonn, Germany; National Museum, Prague, Czech Republic. 


\section{Appendix}

Maximum Likelihood phylogenetic tree of selected amblyceran genera and species on the basis of partial mitochondrial gene COI, with GTR $+\mathrm{I}+\mathrm{G}$ model of molecular evolution. Bootstraps values are next to the nodes (values below 50\% are not shown). $\mathrm{M}=$ species of Myrsidea; $\mathrm{A}=$ species of Apomyrsidea gen. nov.; * = a node between Myrsidea and Apomyrsidea gen. nov.

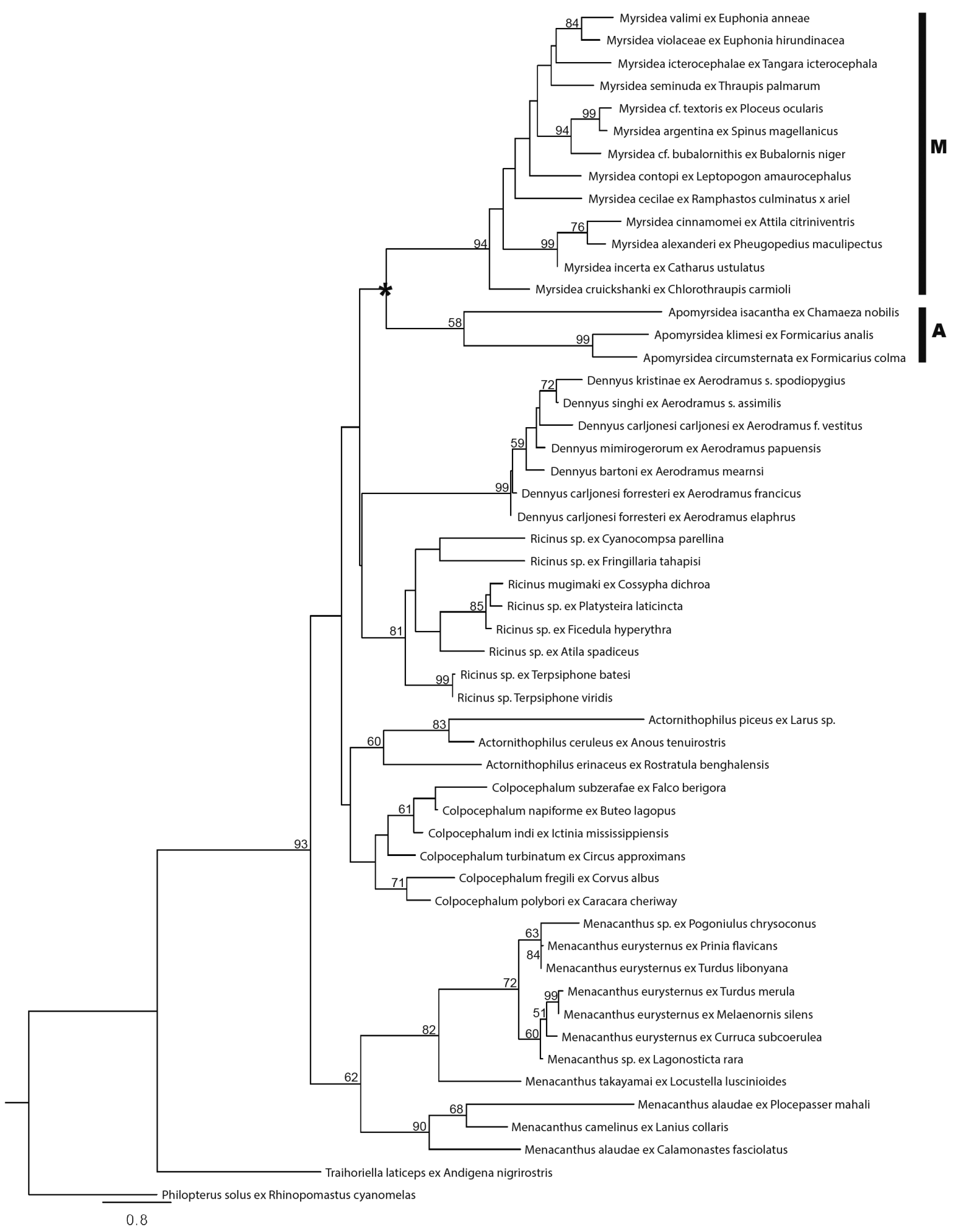

